\title{
Casting a Wide Net: Role of Perineuronal Nets in Neural Plasticity
}

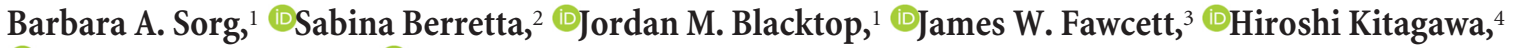 \\ ㄱessica C.F. Kwok, ${ }^{5}$ and ${ }^{\circledR}$ Marta Miquel $^{6}$ \\ ${ }^{1}$ Department of Integrative Physiology and Neuroscience, Translational Addiction Research Center, Washington State University, Vancouver, Washington \\ 98686, ${ }^{2}$ Translational Neuroscience Laboratory, McLean Hospital, Mailman Research Center, Belmont, Massachusetts 02478, ${ }^{3} \mathrm{John}$ van Geest Centre for \\ Brain Repair, Department of Clinical Neurosciences, University of Cambridge, Cambridge CB2 0SP, United Kingdom, ${ }^{4}$ Department of Biochemistry, Kobe \\ Pharmaceutical, University, Kobe 658-8558, Japan, ${ }^{5}$ School of Biomedical Sciences, University of Leeds, Leeds LS2 9JT, United Kingdom, and ${ }^{6}$ Faculty of \\ Health Sciences, Psychobiology, Universitat Jaume I, 12071 Castellón de la Plana, Spain
}

Perineuronal nets (PNNs) are unique extracellular matrix structures that wrap around certain neurons in the CNS during development and control plasticity in the adult CNS. They appear to contribute to a wide range of diseases/disorders of the brain, are involved in recovery from spinal cord injury, and are altered during aging, learning and memory, and after exposure to drugs of abuse. Here the focus is on how a major component of PNNs, chondroitin sulfate proteoglycans, control plasticity, and on the role of PNNs in memory in normal aging, in a tauopathy model of Alzheimer's disease, and in drug addiction. Also discussed is how altered extracellular matrix/PNN formation during development may produce synaptic pathology associated with schizophrenia, bipolar disorder, major depression, and autism spectrum disorders. Understanding the molecular underpinnings of how PNNs are altered in normal physiology and disease will offer insights into new treatment approaches for these diseases.

Key words: aging; Alzheimer's; autism; chondroitin sulfate proteoglycans; drug abuse; extracellular matrix; memory; perineuronal nets; schizophrenia

\section{Introduction}

An emerging concept in neuroscience is that brain plasticity is dependent not only on neurons and glial cells, but also on what is present on the outside of these cells, the extracellular matrix (ECM). This matrix comprises $\sim 20 \%$ of the brain's volume (Nicholson and Syková, 1998) and critically contributes to communication between neurons and glia. Advances in our understanding of the ECM has led to progression from the tripartite theory of synaptic signaling (Araque et al., 1999) to the tetrapartite theory (Dityatev and Rusakov, 2011). If we are to understand

\section{Received July 25, 2016; revised Sept. 7, 2016; accepted Sept. 14, 2016.}

We thank Dr. Megan L. Slaker and Ryan P. Todd (B.A.S. laboratory), Dr. Harry Pantazopoulos (S.B. laboratory), Dr. Daniela Carulli (Netherlands Institute for Neuroscience), Marcello Solinas (INSERM, U1084), and Dolores VazquezSanroman, Maria Carbo-Gas, and Isis Gil-Miravet (M.M. laboratory).

This work was supported by Washington State University Alcohol and Drug Abuse Research Program, National Institutes of Health (NIH) grants DA033404 and DA040965 (to B.A.S. and J.M.B.); NIH grants MH104488, MH091348, MH086522, and MH105608 (to S.B.); Christopher and Dana Reeve International Consortium, European Research Council Advanced Grant, Medical Research Council Programme grant (to J.W.F.); Alzheimers Research UK fellowship (to S. Yang, J.W.F. laboratory); Grants-in-Aid for Scientific Research (B) \#25293014, Scientific Research on Innovative Areas \#23110003, Supported Program for the Strategic Research Foundation at Private Universities, Ministry of Education, Culture, Sports, Science \& Technology, Japan (to H.K.); Wings for Life Foundation, European Research Council (to J.C.F.K.); Supported program for research Universitat Jaume I (14l307.01/1); Supported program for high performance research 2015 (151082.01/1); and Ministerio de Economía y Competitividad (R+D National Program) PSI2015-68600-P (to M.M.).

J.W.F. is a paid advisory board member for Acorda Therapeutics. The other authors declare no competing financial interests.

Correspondence should be addressed to Dr. Barbara A. Sorg, Department of Integrative Physiology and Neuroscience, Washington State University, Vancouver, WA 98662. E-mail: sorg@vetmed.wsu.edu.

D0I:10.1523/JNEUROSCI.2351-16.2016

Copyright $(2016$ the authors $\quad 0270-6474 / 16 / 3611459-10 \$ 15.00 / 0$ normal physiological functioning of the brain, such as learning and memory as well as pathologies underlying brain disorders, we must integrate the contribution by ECM molecules into our understanding of brain signaling processes.

There are three major types of ECM: (1) the "loose" ECM, which is present throughout the brain and spinal cord; (2) the membrane-bound molecules on cells; and (3) the unique, latticelike structures that wrap around specific neurons in the brain and spinal cord called perineuronal nets (PNNs), which tightly interdigitate with synaptic contacts on the soma and proximal dendrites of neurons (Celio et al., 1998; Deepa et al., 2006; Soleman et al., 2013). The focus of this review is on PNNs: their basic structure, function, and role in normal physiological function and brain disorders. PNNs were first described as reticular structures by Golgi in the late 1800s (Spreafico et al., 1999), but only recently has there been intense focus on the role of PNNs in normal brain function, such as learning and memory, and in many disorders or pathologies, such as schizophrenia, Alzheimer's stroke, epilepsy, autism, and drug addiction.

PNNs are unevenly distributed throughout the brain and spinal cord (Seeger et al., 1994). They form during development at different rates across the brain and spinal cord (Brückner et al., 2000; Brückner and Grosche, 2001), completed by early adulthood in the cortex of rodents (Pizzorusso et al., 2002), with differences in developmental rates among cortical subregions (B.A.S. laboratory, unpublished observations). Neural activity promotes PNN development, which occurs at least partly through changes in potassium and calcium 
conductance, and through activation of glutamate receptors (NMDA receptors and calcium-permeable AMPA receptors) (Kalb and Hockfield, 1990; Brückner and Grosche, 2001; Dityatev et al., 2007).

The developmental time window for PNN formation is significant because it marks the period when plasticity is greatly reduced and when the critical period ends. PNNs have been heavily studied for their contributions to critical period plasticity within the visual system, motor system, and somatosensory system (Pizzorusso et al., 2002; Barritt et al., 2006; Massey et al., 2006). A centralizing concept is that PNNs limit plasticity in adulthood and that they can be degraded to reinstate juvenile-like states of plasticity to produce axon sprouting and regeneration of function in damaged neurons. As such, PNNs play key roles in neural development, synaptogenesis, neuroprotection, and experiencedependent synaptic plasticity (Celio et al., 1998; Dityatev and Schachner, 2003; McRae and Porter, 2012; Soleman et al., 2013; Suttkus et al., 2016).

\section{Composition and function of PNNs}

PNNs are formed by four families of ECM molecules. (1) Hyaluronan and its synthesizing enzymes hyaluronan synthases (HASs; HAS1 and HAS3 are found in the CNS); hyaluronin is extruded extracellularly and forms a backbone onto which other PNN molecules bind. (2) Chondroitin sulfate proteoglycans (CSPGs; >15 isoforms are identified in the CNS; for greater detail on the role of CSPGs, see below). Among CSPGs, lectican family members, including aggrecan, versican, neurocan, and brevican, are principal constituents of PNNs (Galtrey and Fawcett, 2007; Kwok et al., 2011). Whereas mice deficient for versican, neurocan, or brevican have largely normal PNNs (Dours-Zimmermann et al., 2009), cortical primary neurons derived from aggrecan-deficient mice are abnormal in that they are not stained by the lectin Wisteria floribunda agglutinin, a broad PNN marker, indicating an essential role for aggrecan in PNN formation (Giamanco et al., 2010). (3) Tenascins (Tn-R is a key component in PNNs). (4) Hyaluronan and proteoglycan link proteins (HAPLNs; HAPLN 1, 3, and 4 are found in the CNS), or simply, "link proteins," which bind to both the hyaluronin backbone and CSPGs to stabilize PNNs (Köppe et al., 1997; Carulli et al., 2007, 2010; Kwok et al., 2010). Link proteins are found in PNNs but not in the loose ECM (Fawcett, 2009). The combination of these molecules creates PNNs of large variety and confers them with diverse biochemical properties. The complexity is further stratified by other modifications, such as sulfation in the chondroitin sulfate (CS) chains (Wang et al., 2008; Lin et al., 2011; Miyata et al., 2012) (for detailed role of CS chains, see below). The composition of CSPGs in PNNs has been distinguished from that present in the loose ECM by using extraction procedures (Deepa et al., 2006). The composition of PNNs varies across brain regions and spinal cord (Matthews et al., 2002; Vitellaro-Zuccarello et al., 2007) and their appearance is different; for example, in some brain regions, PNNs appear as distinct structures that are separate from the loose ECM, whereas in the ventral spinal cord, they are denser with higher intensity labeling of PNNs and the surrounding neuropil (Vitellaro-Zuccarello et al., 2007). Heterogeneity in PNNs and the cell types surrounded by PNNs exists within a single region. For example, in the spinal cord, certain subregions have high levels of CSPGs in PNNs and the presence of the Kv3.1b subunit of the potassium channel, which confers the fast-firing properties in neurons (see paragraph below), whereas other neurons in the spinal cord have low levels of CSPGs in their PNNs and low levels of the Kv3.1b subunit (Vitellaro-Zuccarello et al., 2007).
In general, PNNs are found primarily around fast-spiking, parvalbumin (PV)-containing GABAergic interneurons within many brain regions (Härtig et al., 1992; Schüppel et al., 2002; Dityatev et al., 2007). However, PNNs also surround glutamatergic neurons (Wegner et al., 2003; Mészár et al., 2012; HoriiHayashi et al., 2015; Vazquez-Sanroman et al., 2015a; Yamada et al., 2015), which can be both PV positive or negative (Mészár et al., 2012; Horii-Hayashi et al., 2015). Given their location surrounding fast-spiking interneurons, PNNs are in a prime position to alter the excitatory/inhibitory balance and thus regulate output of these regions. PNNs are thought to protect neurons from oxidative stress (Morawski et al., 2004; Cabungcal et al., 2013), perhaps by limiting GABAergic interneuron excitability. It is hypothesized that PNNs play a role in regulating neural plasticity via three mechanisms (Fig. 1) (Wang and Fawcett, 2012): (1) altering the formation of new neuronal contacts (Corvetti and Rossi, 2005; Barritt et al., 2006); (2) acting as a scaffold for molecules that can inhibit synaptic formation (Deepa et al., 2002); and (3) limiting receptor motility at synapses (Frischknecht et al., 2009).

\section{Role of CSPGs during development}

CSPGs consist of core proteins with one or more covalently attached CS chains. Studies from the H.K. laboratory have focused on the role of sulfation patterns of CSPGs in neural development. The importance of sulfation patterns of CS chains in such plasticity has been overlooked in previous studies because chondroitinase- $\mathrm{ABC}$ (Ch$\mathrm{ABC}$ ) destroys all CS chains, regardless of CS sulfation status. CS chains are long linear polysaccharides composed of repeating disaccharide units; each unit comprises a glucuronic acid and an $\mathrm{N}$ acetylgalactosamine residue. During biosynthesis, individual $\mathrm{N}$-acetylgalactosamine residues of the repeated disaccharide units can be sulfated by chondroitin 6-O-sulfotransferase-1 (C6ST-1) or chondroitin 4-O-sulfotransferase-1, thereby generating 6-sulfation or 4-sulfation, respectively (Mikami and Kitagawa, 2013; Miyata and Kitagawa, 2015).

Notably, there are drastic changes in the sulfation patterns of CS chains during the formation of PNNs. Specifically, 6-Osulfation is dominant in the juvenile brain to produce C6S, which is more permissive (Lin et al., 2011; Miyata et al., 2012), whereas 4-O-sulfation becomes dominant in the adult brain to produce chondroitin sulfate with 4-O-sulfation $(\mathrm{C} 4 \mathrm{~S})$, which is the most inhibitory form of CS: it inhibits the growth of cerebellar granular neurons in culture and is upregulated in regions that do not support axonal growth after spinal cord injury (Deepa et al., 2006; Wang et al., 2008). Overall then, there is a substantial increase in the 4-sulfation/6-sulfation (C4S/C6S) ratio during brain development (Kitagawa et al., 1997; Miyata et al., 2012). The percentages of both C6S and another isoform, chondroitin 4,6-disulfate (CS-E), decrease drastically after birth and remain at a low level in adults. However, there is an enrichment of C6S and CS-E in the PNNs compared with the CSs isolated from the loose brain ECM (Deepa et al., 2006; Dick et al., 2013). The shift in sulfation patterns is essential for PNN formation: transgenic mice with reduced C6S show poor regeneration after a lesion in the CNS (Lin et al., 2011), and transgenic mice overexpressing C6ST-1 retain juvenile-like CS sulfation and show impaired PNN formation (Miyata et al., 2012). In addition, overexpression of C6ST-1 prevents the maturation of electrophysiological properties of PV-expressing interneurons and reduces the inhibitory effects of these PV cells because of impaired PNN formation. As a result, transgenic mice overexpressing C6ST-1 

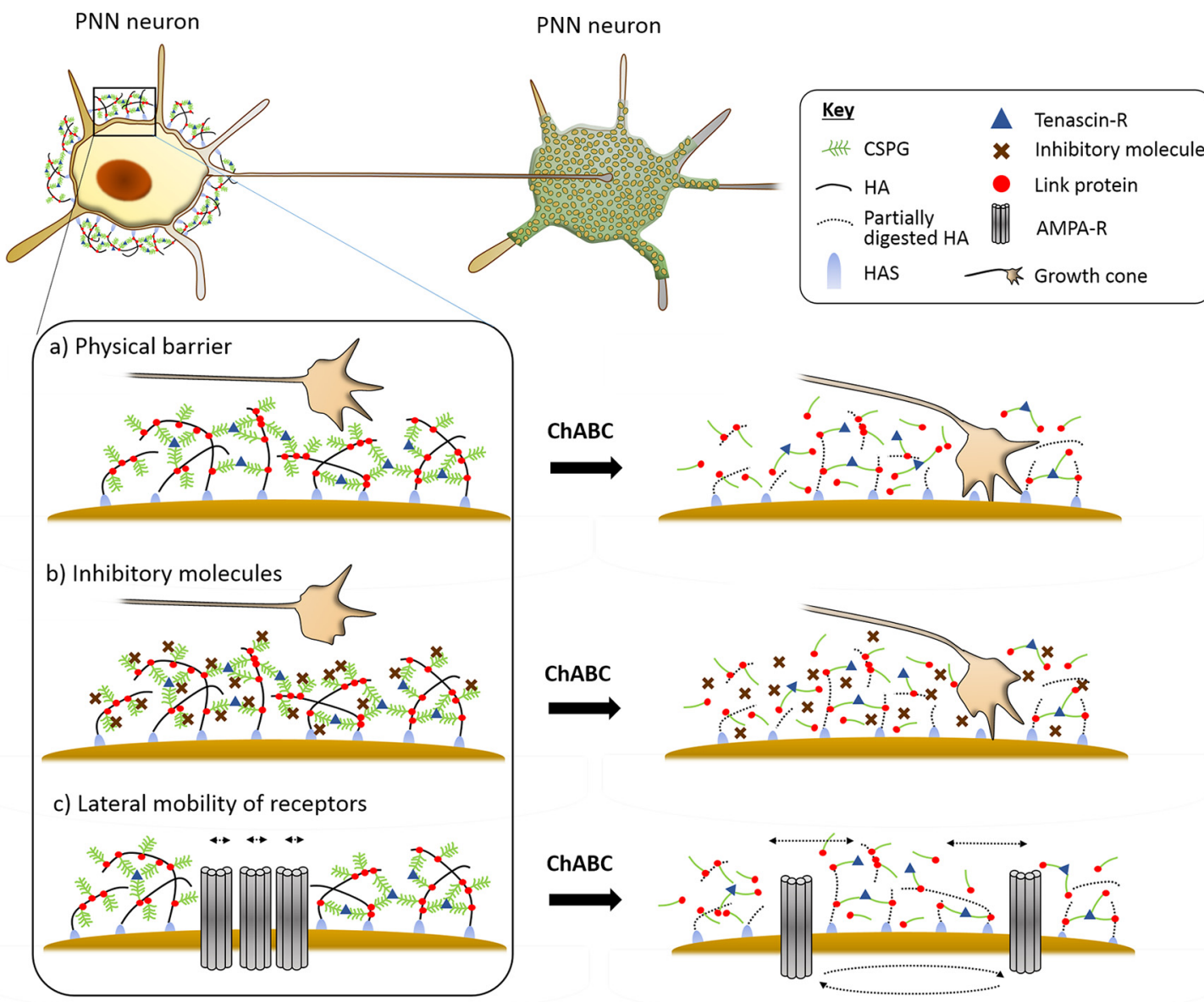

Figure 1. Limitation of plasticity by PNNs via three mechanisms and reinstatement of plasticity by treatment with Ch-ABC. Plasticity involving PNN-surrounded neurons is limited by the following: (a) a physical barrier by PNNs to incoming synaptic inputs; (b) binding of molecules via specific sites on CSPGs of PNNs (molecules, such as semaphorin 3A, inhibit new synaptic inputs); and (c) prevention of lateral diffusion of AMPA receptors, limiting the ability to exchange desensitized receptors in the synapse for new receptors from extrasynaptic sites. Treatment with Ch-ABC disrupts PNNs, reinstating juvenile-like states of plasticity. HA, Hyaluronic acid; HAS, hyaluronic acid synthase. Figure courtesy of J.C.F. Kwok. Modified from Wang and Fawcett (2012), with permission.

retain a juvenile level of ocular dominance plasticity even in adulthood (Miyata et al., 2012). Interestingly, overexpression of C6ST-1 selectively decreases aggrecan in the aged brain without affecting other PNN components. In addition, the increased 6-sulfation accelerates proteolysis of aggrecan by a disintegrin and metalloproteinase domain with thrombospondin motif (ADAMTS) protease (Miyata and Kitagawa, 2016). These results indicate that sulfation patterns of CS chains on aggrecan influence the stability of the CSPG, thereby regulating formation of $\mathrm{PNNs}$ and neural plasticity, and overall, the CS chains regulate the plasticity characteristic of the critical period.

Alteration of C6ST-1 expression and CS sulfation patterns are found in brains of human patients with bipolar disorder or schizophrenia and mice with cortical brain injury (Yi et al., 2012; Okuda et al., 2014; Pantazopoulos et al., 2015) (see also below). Notably, chondroitin 6-sulfation and chondroitin 6-sulfationenriched PNNs increase in the mouse cerebral cortex after kainic acid treatment; simultaneously, chondroitin 4-sulfation-enriched PNNs and the 4S/6S ratio decrease. Furthermore, C6ST-1 TG mice are more susceptible to kainic acid-induced seizures than wild-type mice (Yutsudo and Kitagawa, 2015). These results suggest that chondroitin 6-sulfation is relevant to epilepsy most likely because of dysregulated PNN formation and PV cell maturation, and that an abnormal balance of 4-sulfation and 6-sulfation produced by both neurons and astrocytes may contribute to the disease.

\section{Role of PNNs in memory, aging, and an Alzheimer's disease model}

Memory is a form of plasticity, so it is reasonable to ask whether PNN interventions affect memory. The first memory model to be explored was fear conditioning, which involves the amygdala. $\mathrm{Ch}-\mathrm{ABC}$ treatment does not affect fear conditioning, but it restores the ability to reverse or unlearn the conditioning (Gogolla et al., 2009). This enzyme treatment also enhances reversal learning in the auditory cortex (Happel et al., 2014). In contrast, PNN removal has also been shown to prevent plasticity induced by fear conditioning (Hylin et al., 2013) and impairs certain aspects of learning/memory in animal models of addiction (see Addiction models).

The J.W.F. laboratory has recently focused on object recognition memory, which relies on the tendency of rodents to investigate novel objects in preference to familiar ones, and it relies on the perirhinal cortex (PrC). Digestion of CSPGs in PrC or transgenic attenuation of PNNs had the effect of greatly extending object memory, from 12 to $96 \mathrm{~h}$ (Romberg et al., 2013). This was unexpected; greater plasticity might mean more rapid turnover. A possible explanation came from the work of the Caroni labo- 
ratory, looking at synaptic changes during memory. In the hippocampus, a memory task leads to an increased number of inhibitory synapses on PV interneurons, reducing their GABA production and thereby promoting cortical excitability (Donato et al., 2013). Ch-ABC treatment has exactly the same effect on this late-born population of $\mathrm{PV}$ neurons in both the hippocampus and $\mathrm{PrC}$, providing a possible link to the effect of PNN removal on memory.

Prolongation of object memory is probably not very useful. However, in situations where memory is defective, restoration would be valuable. Transgenic mice that overexpress a mutant form of tau that gives tauopathy and dementia in humans provide a model for Alzheimer's disease and related conditions (Allen et al., 2002). These mice develop neurofibrillary tangles and hyperphosphorylation of tau, with obviously dystrophic neurons by 3 months and neuronal loss after 4 months. This translates to a profound loss of object memory by 3 months. Treating these animals with $\mathrm{Ch}-\mathrm{ABC}$ to the $\mathrm{PrC}$ restored object memory to normal levels (Yang et al., 2015), and transgenic attenuation of PNNs in tauopathy mice delays by several weeks the onset of memory loss. How might these interventions act to restore memory? Two mechanisms are likely: (1) Ch-ABC treatment enables sprouting of axons to create bypass circuits, and this may enable the CNS to bypass dysfunctional neurons affected by tau pathology; and (2) removal of PNNs may make it easier for memories to form, based on easier access for new inhibitory synapses onto PV neurons, leading to reduced GABA inhibition of cortical circuits.

Memory loss is a feature of aging even in the absence of Alzheimer's disease. This can be seen in aged mice, which have a marked deficit in memory retention at 18 months of age. Again, $\mathrm{Ch}-\mathrm{ABC}$ injections to the $\mathrm{PrC}$ can restore object memory, or injections to the hippocampus restore object place memory ( $\mathrm{S}$. Yang, unpublished results). The deterioration of memory with age has usually been assumed to be caused by a decrease in the number of synapses with age. However, there is a possible alternative PNN-based mechanism. The findings that CS sulfation patterns are different across development together with the idea that mice with enhanced C6S production have increased plasticity prompted the J.C.K. and J.W.F. laboratories to ask the question: do PNNs in aging brains, where plasticity has been drastically reduced, show different sulfation composition than young brains? Biochemical analysis of isolated brain glycans from 3 - to 18 -month old brains shows that there is a threefold reduction of C6S in the PNNs from 12- and 18-month old brains. This reduction is specific to the PNNs and is not observed in young brains or in the general brain ECM (S. Foscarin et al., unpublished results). This change almost eliminates the permissive $\mathrm{C} 6 \mathrm{~S}$, leaving only 4-sulfated forms (D. Carulli, unpublished results). This might be expected to make PNNs yet more inhibitory and to block the formation of new synapses on PV neurons that underlie memory.

These changes could explain the loss of plasticity in aged animals. In addition to acting directly on neuronal growth, CSs also modulate growth and plasticity by binding to different molecules in the ECM. The chemorepulsive molecule semaphorin 3A binds specifically to PNNs via CS-E (found in adults), and this binding exerts an additional level of inhibition of PNN matrix to the growth of neurons (Dick et al., 2013; Vo et al., 2013). The transcription factor Otx-2 also binds to the CS-E in the PNNs and thus regulates the maturation of neurons and the duration of the critical period, a time period when the CNS remains plastic during visual cortex development (Beurdeley et al., 2012; Spatazza et al., 2013). These studies suggest that the functions of PNNs are heavily dependent on the composition of PNN components and their assembly. They present a promising avenue for plasticity enhancement to improve CNS pathologies through PNN manipulation.

In summary, PNNs have many potential sites for therapeutic action. Compounds acting on the PNN will not slow the progression of the pathology of Alzheimer's disease or prevent aging. However, based on the current rodent results, there is a strong possibility that PNN interventions will enable the brain to keep working despite the underlying pathology.

\section{Role of PNNs in psychiatric disorders}

Rapidly emerging evidence points to ECM abnormalities as a key component of the pathophysiology of psychiatric disorders, including schizophrenia (S.B. laboratory), bipolar disorder, major depression, autism, and addiction (see Addiction models) (Berretta, 2012; Folsom and Fatemi, 2013; Berretta et al., 2015). Disruption of PNNs has been particularly well documented in schizophrenia, with marked decreases of CSPG-labeled PNNs in the amygdala, entorhinal cortex, and PFC (Pantazopoulos et al., 2010, 2015; Mauney et al., 2013). These interconnected brain regions are involved in emotion-related learning and associative sensory information processing and in the pathophysiology of this disorder (Prasad et al., 2004; Berretta et al., 2007; Pantazopoulos et al., 2015). PNN decreases are accompanied by altered CSPG expression in glial cells (Pantazopoulos et al., 2010, 2015), a significant finding because these cells represent the main contributors to the ECM/PNNs molecular building blocks (Faissner et al., 2010) (see also above). Additional support comes from human genetic and postmortem studies pointing to the involvement of key ECM/PNN molecules, including CSPGs, Reelin, semaphorin 3A, integrins, and remodeling enzymes, such as metalloproteinases in schizophrenia (Guidotti et al., 2000b; Eastwood et al., 2003; Schizophrenia Working Group of the Psychiatric Genomics Consortium, 2014).

Similar findings have been reported in bipolar disorder and major depression. For instance, decreased Reelin expression has been observed in the PFC, hippocampus, and cerebellum, as well as in blood of subjects with bipolar disorder or major depression (Guidotti et al., 2000a; Fatemi, 2005). Postmortem studies in the S.B. laboratory on bipolar disorder show marked decreases of PNNs across several nuclei in the amygdala (Pantazopoulos et al., 2015).

Multiple lines of evidence implicate ECM abnormalities in autism spectrum disorders. Genome-wide association studies on autism implicate a number of ECM and PNN regulating molecules, including the ECM remodeling enzymes, ECM molecules Reelin, semaphorins $3 \mathrm{~A}$ and $4 \mathrm{D}$, the hyaluronan surface receptor CD44, and Otx-2, a transcription factor involved in PNN formation (e.g.Weiss et al., 2009; Hussman et al., 2011). By far, the strongest evidence for ECM involvement in the pathophysiology of autism comes from investigations on Reelin. Consistent with these findings, altered expression of Reelin and its signaling pathways has been observed in the frontal, parietal, and cerebellar cortices of subjects with autism (Fatemi et al., 2005). Similarly, involvement of ECM/PNN molecules has been reported in Fragile X syndrome and Rett syndrome, this latter also shown to have PNN abnormalities (Belichenko et al., 1997; Dziembowska et al., 2013).

During development and in adulthood, ECM/PNN molecules and their cell surface receptors mediate a broad range of synaptic regulatory functions impacting dendritic spine and synapse structure and plasticity as well as glutamatergic and GABAergic 
transmission (Faissner et al., 2010; Dityatev and Rusakov, 2011; Frischknecht and Gundelfinger, 2012). Evolving in parallel with our understanding of these functions, evidence for ECM/PNN pathology in psychiatric disorders supports the intriguing hypothesis that ECM/PNN abnormalities may contribute to a critical pathological component shared by psychiatric disorders (i.e., disruption of synaptic functions) (e.g., Penzes et al., 2013; Duman, 2014; Xu et al., 2014). These may include well-documented synaptic pathology in these disorders, including loss of dendritic spines, presynaptic and postsynaptic regulatory elements, and disruption of glutamatergic synaptic signaling and GABAergic inhibitory neuron functions. In addition to synaptic dysregulation, critical functions performed by the ECM during brain development and adulthood (Bandtlow and Zimmermann, 2000; Tissir and Goffinet, 2003; Maeda et al., 2010; Kwok et al., 2011) suggest that the consequences of brain ECM abnormalities in psychiatric disorders may be complex and far-reaching, affecting several aspects of neural connectivity (Rhodes and Fawcett, 2004; Syková, 2004; Berretta, 2008, 2012; Fatemi, 2010; McRae and Porter, 2012; Lubbers et al., 2014; Berretta et al., 2015; Fawcett, 2015).

Potentially integral to disruption of glutamatergic/GABAergic function in psychiatric disorders (including addiction) is the possibility that PNNs contribute substantially to the excitatory/ inhibitory balance because they surround PV-containing fastspiking GABAergic interneurons in the PFC. These interneurons are central for generating gamma oscillations $(30-120 \mathrm{~Hz})$, and their removal alters these oscillations (Steullet et al., 2014). Gamma oscillations underlie synchronous network activity that mediates information processing and cognitive flexibility that is impaired in schizophrenia (Cho et al., 2006, 2015; Minzenberg et al., 2010), consistent with the observation that PV neurons do not develop normally in schizophrenia (Lewis et al., 2005) or in autism (Orekhova et al., 2007).

\section{Role of PNNs in addiction models}

Addiction is a psychiatric disease whose aberrant strength and persistence of drug-induced memories are believed to have a primary role in drug seeking and relapse (Everitt and Robbins, 2005; Kalivas and Volkow, 2005; Hyman et al., 2006). Cocaine-induced neuroplasticity of the ECM has been reported in both cocainedependent humans (Mash et al., 2007) and rodent models of cocaine addiction (Van den Oever et al., 2010; Smith et al., 2014; for review, see Lubbers et al., 2014; Smith et al., 2015). Relatively few studies have characterized the expression of PNNs in brain regions implicated in addiction: the striatum, ventral pallidum, amygdala, PFC, hippocampus, hypothalamus, and cerebellum (Härtig et al., 1992; Seeger et al., 1994; Bertolotto et al., 1996; Hobohm et al., 1998).

The striatum, including the nucleus accumbens, caudate nucleus, and putamen, is heavily implicated in reward and motivated behaviors. Low levels of sporadic PNN staining have been reported in all three regions of the striatum in the rat (Seeger et al., 1994; Bertolotto et al., 1996); in contrast, in the mouse, significant and functional PNN expression has been reported throughout the striatum (Lee et al., 2012). The ventral pallidum is essential for the integrative component of the limbic system contributing to motivated behavior and drug seeking (Kalivas and Volkow, 2005; Smith et al., 2009; Mahler et al., 2014). This region exhibits robust PNN expression (Seeger et al., 1994), making it a promising brain region with regard to the role of PNNs in motivated behavior, but to date, it has not been studied in this context.
Only a handful of studies in rats and mice have thus far examined the role of PNNs in addiction models (for review, see Slaker et al., 2016), with a focus on the amygdala, the PFC (B.A.S. laboratory; see below), and the cerebellum (M. M. laboratory; see below).

The amygdala is well situated between the PFC and the ventral striatum to provide key neurocircuitry mediating both stressand cue-induced reinstatement of drug-seeking behavior (Cardinal et al., 2002; Kalivas and Volkow, 2005). Studies on PNN expression differ between species within the amygdala. Early studies examining the amygdala of the rodent reported relatively low PNN expression (Seeger et al., 1994; Bertolotto et al., 1996); however, a study examining the BLA of humans reported significant PNN expression (Pantazopoulos et al., 2008). A more recent study in the amygdala in rats has shown that $\mathrm{PNN}$ degradation by $\mathrm{Ch}-\mathrm{ABC}$ following drug exposure (morphine, cocaine, and heroin) but before extinction training augments extinction and inhibits subsequent reinstatement (relapse) of drug-seeking behavior (Xue et al., 2014).

Proteins from the ECM, including those in PNNs, are decreased in the PFC after heroin self-administration but rapidly elevated after reexposure to heroin-associated cues (Van den Oever et al., 2010). The B.A.S. laboratory focused on the impact of cocaine on PNNs in the $\mathrm{mPFC}$ and found that a single injection of cocaine rapidly decreased PNN intensity $2 \mathrm{~h}$ later, whereas five daily injections increased PNN intensity 2 h later (B.A.S., unpublished findings); the latter finding is consistent with increased PNN staining after repeated ethanol exposure in another cortical region, the insular cortex (Chen et al., 2015). The potential significance of initial decreases followed by later increases in PNN intensity after drug exposure is the idea that decreased PNN staining intensity appears to correspond to an immature PNN with increased capacity for plasticity, whereas increased PNN intensity corresponds to a mature PNN with decreased capacity for plasticity (Wang and Fawcett, 2012). The changes in PNN intensity after cocaine are consistent with the idea that initial learning ( $1 \mathrm{~d}$ cocaine) decreases PNN intensity and may allow for greater cocaine-induced plasticity, whereas repeated cocaine (5 d cocaine) may "stamp in" synaptic changes, as discussed below for the cerebellum, rendering the circuitry more impervious to plasticity induced by other stimuli, such as natural rewards. In addition, PV staining mirrored the changes in PNN staining after cocaine, but the changes lagged behind those of PNNs, suggesting that PNNs and PV may be coregulated in some way, and that cocaine-induced changes may significantly alter GABAergic output from these interneurons due to altered PV content (Donato et al., 2013). Overall, cocaine-induced metaplasticity appears to restrict the formation of new plasticity (Moussawi et al., 2009; Kasanetz et al., 2010), setting in place neural connectivity underlying addictive behaviors, and PNNs may play a role in this restriction of plasticity. Interestingly, some of the effects of cocaine on PV/PNN changes may be related to oxidative stress. Cocaine produces oxidative stress in neurons (Dietrich et al., 2005; Numa et al., 2008; Sordi et al., 2014; Jang et al., 2015). PNNs protect against oxidative stress (Morawski et al., 2004; Cabungcal et al., 2013), and consistent with this protection, unpublished findings in the B.A.S. laboratory found that the antioxidant $N$-acetyl cysteine reverses the relatively small increases in an oxidative stress marker in the mPFC after cocaine in PV neurons that are surrounded by PNNs, but not the larger increases in this marker in PV neurons devoid of PNNs.

The results that cocaine-induced plasticity restricts further plasticity are in accordance with recent work demonstrating that degrading $\mathrm{PNN}$ s with $\mathrm{Ch}-\mathrm{ABC}$ in the $\mathrm{mPFC}$ reduced the acquisition and/or 
maintenance (reconsolidation) of cocaine memory in a conditioned place preference model of addiction in rats (Slaker et al., 2015) and blunted the ability of rats to learn cocaine self-administration (B.A.S., unpublished findings). In addition, PNNs in another brain area contribute to cocaine-induced memories: a region of the anterior dorsal lateral hypothalamic area was recently discovered to exhibit a small patch of dense, robust PNN and loose ECM expression. Degradation of this patch with $\mathrm{Ch}-\mathrm{ABC}$ abolished the acquisition of cocaine- but not sucrose-induced cocaine conditioned place preference and also the acquisition of cocaine but not sucrose selfadministration (J.M.B., unpublished findings).

Consistent with the idea that cocaine alters the intensity of PNNs and associated plasticity, studies in the M.M. laboratory have focused on the role of the cerebellum in cocaine addiction models; these studies suggest that local circuits in the apex of the cerebellar cortex might be an important and largely overlooked part of the networks involved in forming, maintaining and/or retrieving drug memories that underlie relapse (Carbo-Gas et al., 2014a, b; Miquel et al., 2016). Using a preference conditioning paradigm with cocaine exposure, the Miquel laboratory observed that PNNs surrounding Golgi inhibitory interneurons in the apex of the cerebellar cortex are upregulated (more intensely labeled), but only in those animals that prefer the cue associated with cocaine (M. Miquel, unpublished data). Aside from more intensely stained PNNs around Golgi neurons, neighboring granule cells show elevated levels of activity (estimated by cFos expression) that correlates with preference toward the cocainerelated cue (Carbo-Gas et al., 2014a, b). Remarkably, neither of these distinctive cerebellar signatures occurs when animals do not express cocaine-induced preference conditioning.

It is now clear that PNNs restrict the capacity of their wrapped neurons for experience-dependent plasticity (Pizzorusso et al., 2002). Of note, Golgi neurons play a crucial role in modulating the activity and plasticity of local circuits in the cerebellar cortex (Mapelli and D'Angelo, 2007; Roggeri et al., 2008; D'Angelo and De Zeeuw, 2009; D'Angelo et al., 2013). Consequently, one could speculate that a fully condensed PNN surrounding Golgi neurons, which is found only in mice that have acquired conditioned preference for cocaine, might "stamp in" synaptic changes related to cue-drug associations, thereby preventing posterior synaptic rearrangements in the local circuits of the granule cell layer.

Cocaine-induced changes in PNN expression in the cerebellum show anatomical specificity and different functional regulation. Indeed, PNNs that surround large glutamatergic projection neurons in the medial deep cerebellar nucleus (DCN) are not changed after acquisition of cocaine-induced preference memory, but after a short withdrawal period, the expression of PNNs increases around DCN neurons (Vazquez-Sanroman et al., 2015a). More intensely stained PNNs are associated with molecular and structural plasticity changes in Purkinje cells that reduce their capacity to inhibit DCN neurons. Following a longer withdrawal period, Purkinje neurons develop opposite plasticity changes, including dendritic sprouting and enlarged terminal size (Vazquez-Sanroman et al., 2015b). In this case, PNNs are downregulated in DCN neurons. More lightly stained PNNs (i.e., less PNN material around the cell) might facilitate the subsequent remodeling of Purkinje-DCN synapses (Vazquez-Sanroman et al., 2015b). Together, these findings point toward different functions for cerebellar PNNs in drug-related plasticity. The PNNs around Golgi neurons would act as "brain tattoos" (Hustvedt, 2014) to stabilize long-term drug memory encoded in local circuits of the cerebellar cortex. However, those that wrap DCN projection neurons would serve as "temporary stickers" to dy- namically control the cerebellar output by promoting or restricting plasticity in Purkinje-DCN synapses.

In summary, changes in PNNs are rapid and regulated by both drug exposure and its associated memory. Although the changes in PNN staining intensity (increases or decreases) are likely to depend on the particular drug, the extent of drug exposure, and withdrawal time from the drug, the functional outcome of these dynamic changes has yet to been tested. Although the contribution of PNNs to both drug-induced neuroplasticity and behavior is in its infancy, increased PNN staining intensity found around neurons after repeated exposure to cocaine suggests that these neurons may be less malleable to plasticity induced by naturally rewarding stimuli.

The emerging pattern of changes in PNNs after exposure to drugs of abuse supports the concept that these structures regulate plasticity and likely firing patterns of their underlying neurons, which in turn alter drug-seeking behavior, making PNNs potential therapeutic targets in addiction.

\section{Limitations, future directions, and conclusions}

One of the current limitations in understanding the contribution by PNNs in brain and spinal cord plasticity is that the enzyme Ch-ABC has been used almost exclusively to degrade PNNs. However, Ch-ABC also destroys the loose ECM, and therefore the contribution of PNNs is not entirely clear. However, strong evidence supports a key contribution by PNNs to critical period closure for ocular dominance plasticity because knock-out mice that lack a key link protein demonstrate reduced formation of PNNs, but no changes in the loose ECM, and they maintain juvenile levels of ocular dominance plasticity (Carulli et al., 2010). One potential future direction is to specifically knock down cartilage link protein-1 to reduce PNN formation (Carulli et al., 2010) because this protein is found only in PNNs but not in loose ECM (Galtrey et al., 2008). Unpublished findings (B.A.S.) demonstrate that a morpholino that interferes with cartilage link protein-1 expression reduces PNN intensity and number, but future studies will need to determine the functional consequences of this knockdown strategy. Other strategies are to target local expression of Otx-2, which maintains PNNs (Beurdeley et al., 2012; Bernard and Prochiantz, 2016), as well as other molecules, such as semaphorin $3 \mathrm{~A}$, to regulate synaptic inputs (Dick et al., 2013; Vo et al., 2013; de Winter et al., 2016) or neuronal pentraxin-2 (NARP) (Gu et al., 2013), which regulates PV neuron excitation through recruitment of glutamate (AMPA) receptors (Chang et al., 2010; Pelkey et al., 2015).

In conclusion, recent discoveries show that PNN formation contributes to a loss of brain plasticity in adults, and that brain and spinal cord plasticity can be reestablished in adults after removal of PNNs. Dynamic changes in PNNs appear after environmental manipulations. Overall, decreases in PNN intensity may be associated with increased inhibitory input to their underlying neurons, whereas increases in PNN intensity may be associated with increased excitatory input to these neurons. Increased excitatory input might be expected to promote PNN formation, given that one proposed function of PNNs is to provide a highly anionic environment to maintain ion-buffering capacity around their typically highly active cells (Brückner et al., 1993; Härtig et al., 1999). PNN formation may therefore limit firing to protect neurons from oxidative stress, and as a consequence, reduce plasticity in response to environmental stimuli-induced plasticity by binding of PNNs to chemorepellant molecules, such as semaphorin 3A. This limitation of firing by PNNs is in accordance with reports that removal of $\mathrm{PNNs}$ with $\mathrm{Ch}-\mathrm{ABC}$ renders their underlying neurons more active (Dityatev et al., 2007) and pro- 
duces greater high-frequency ( $\beta$ and $\gamma$ ) oscillations (Steullet et al., 2014) (B.A.S., unpublished observations).

The changes imposed by drug or environmental stimuli, in addition to interference with normal development of PNNs, may contribute to a wide range of diseases and disorders of the brain, including Alzheimer's, autism, epilepsy, schizophrenia, bipolar disorder, aging, brain injury, and learning and memory, including that associated with drug abuse. However, many questions remain, including the functional significance of changes in staining intensity of PNNs and how PNN removal is capable of both enhancing plasticity to imposed environmental stimuli, such as repetitive motor movements after spinal cord damage but paradoxically attenuating the learning/memory associated with other environmental manipulations, such as fear conditioning and drugs of abuse. Understanding the molecular underpinnings of how PNNs are altered in normal physiology and disease is expected to offer insights into new treatment approaches for these diseases.

\section{References}

Allen B, Ingram E, Takao M, Smith MJ, Jakes R, Virdee K, Yoshida H, Holzer M, Craxton M, Emson PC, Atzori C, Migheli A, Crowther RA, Ghetti B, Spillantini MG, Goedert M (2002) Abundant tau filaments and nonapoptotic neurodegeneration in transgenic mice expressing human P301S tau protein. J Neurosci 22:9340-9351. Medline

Araque A, Parpura V, Sanzgiri RP, Haydon PG (1999) Tripartite synapses: glia, the unacknowledged partner. Trends Neurosci 22:208-215. CrossRef Medline

Bandtlow CE, Zimmermann DR (2000) Proteoglycans in the developing brain: new conceptual insights for old proteins. Physiol Rev 80:12671290. Medline

Barritt AW, Davies M, Marchand F, Hartley R, Grist J, Yip P, McMahon SB, Bradbury EJ (2006) Chondroitinase ABC promotes sprouting of intact and injured spinal systems after spinal cord injury. J Neurosci 26:1085610867. CrossRef Medline

Belichenko PV, Hagberg B, Dahlström A (1997) Morphological study of neocortical areas in Rett syndrome. Acta Neuropathol 93:50-61. CrossRef Medline

Bernard C, Prochiantz A (2016) Otx2-PNN interaction to regulate cortical plasticity. Neural Plast 2016:7931693. Medline

Berretta S (2008) Astrocytes in the pathophysiology of schizophrenia: abnormal expression of extracellular matrix molecules. Schizophr Res 102: 11. CrossRef

Berretta S (2012) Extracellular matrix abnormalities in schizophrenia. Neuropharmacology 62:1584-1597. CrossRef Medline

Berretta S, Pantazopoulos H, Lange N (2007) Neuron numbers and volume of the amygdala in subjects diagnosed with bipolar disorder or schizophrenia. Biol Psychiatry 62:884-893. CrossRef Medline

Berretta S, Pantazopoulos H, Markota M, Brown C, Batzianouli ET (2015) Losing the sugar coating: potential impact of perineuronal net abnormalities on interneurons in schizophrenia. Schizophr Res 167:18-27. CrossRef Medline

Bertolotto A, Manzardo E, Guglielmone R (1996) Immunohistochemical mapping of perineuronal nets containing chondroitin unsulfated proteoglycan in the rat central nervous system. Cell Tissue Res 283:283-295. CrossRef Medline

Beurdeley M, Spatazza J, Lee HH, Sugiyama S, Bernard C, Di Nardo AA, Hensch TK, Prochiantz A (2012) Otx2 binding to perineuronal nets persistently regulates plasticity in the mature visual cortex. J Neurosci 32:9429-9437. CrossRef Medline

Brückner G, Grosche J (2001) Perineuronal nets show intrinsic patterns of extracellular matrix differentiation in organotypic slice cultures. Exp Brain Res 137:83-93. CrossRef Medline

Brückner G, Brauer K, Härtig W, Wolff JR, Rickmann MJ, Derouiche A, Delpech B, Girard N, Oertel WH, Reichenbach A (1993) Perineuronal nets provide a polyanionic, glia-associated form of microenvironment around certain neurons in many parts of the rat brain. Glia 8:183-200. CrossRef Medline

Brückner G, Grosche J, Schmidt S, Härtig W, Margolis RU, Delpech B, Seidenbecher CI, Czaniera R, Schachner M (2000) Postnatal development of perineuronal nets in wild-type mice and in a mutant deficient in tenascin-R. J Comp Neurol 428:616-629. CrossRef Medline
Cabungcal JH, Steullet P, Morishita H, Kraftsik R, Cuenod M, Hensch TK, Do KQ (2013) Perineuronal nets protect fast-spiking interneurons against oxidative stress. Proc Natl Acad Sci U S A 110:9130-9135. CrossRef Medline

Carbo-Gas M, Vazquez-Sanroman D, Aguirre-Manzo L, Coria-Avila GA, Manzo J, Sanchis-Segura C, Miquel M (2014a) Involving the cerebellum in cocaine-induced memory: pattern of cFos expression in mice trained to acquire conditioned preference for cocaine. Addict Biol 19:61-76. CrossRef Medline

Carbo-Gas M, Vazquez-Sanroman D, Gil-Miravet I, De las Heras-Chanes J, Coria-Avila GA, Manzo J, Sanchis-Segura C, Miquel M (2014b) Cerebellar hallmarks of conditioned preference for cocaine. Physiol Behav 132:24-35. CrossRef Medline

Cardinal RN, Parkinson JA, Hall J, Everitt BJ (2002) Emotion and motivation: the role of the amygdala, ventral striatum, and prefrontal cortex. Neurosci Biobehav Rev 26:321-352. CrossRef Medline

Carulli D, Rhodes KE, Fawcett JW (2007) Upregulation of aggrecan, link protein 1 , and hyaluronan synthases during formation of perineuronal nets in the rat cerebellum. J Comp Neurol 501:83-94. CrossRef Medline

Carulli D, Pizzorusso T, Kwok JC, Putignano E, Poli A, Forostyak S, Andrews MR, Deepa SS, Glant TT, Fawcett JW (2010) Animals lacking link protein have attenuated perineuronal nets and persistent plasticity. Brain 133:2331-2347. CrossRef Medline

Celio MR, Spreafico R, De Biasi S, Vitellaro-Zuccarello L (1998) Perineuronal nets: past and present. Trends Neurosci 21:510-515. CrossRef Medline

Chang MC, Park JM, Pelkey KA, Grabenstatter HL, Xu D, Linden DJ, Sutula TP, McBain CJ, Worley PF (2010) Narp regulates homeostatic scaling of excitatory synapses on parvalbumin-expressing interneurons. Nat Neurosci 13:1090-1097. CrossRef Medline

Chen H, He D, Lasek AW (2015) Repeated binge drinking increases perineuronal nets in the insular cortex. Alcohol Clin Exp Res 39:19301938. CrossRef Medline

Cho KK, Hoch R, Lee AT, Patel T, Rubenstein JL, Sohal VS (2015) Gamma rhythms link prefrontal interneuron dysfunction with cognitive inflexibility in Dlx5/6(+/-) mice. Neuron 85:1332-1343. CrossRef Medline

Cho RY, Konecky RO, Carter CS (2006) Impairments in frontal cortical gamma synchrony and cognitive control in schizophrenia. Proc Natl Acad Sci U S A 103:19878-19883. CrossRef Medline

Corvetti L, Rossi F (2005) Degradation of chondroitin sulfate proteoglycans induces sprouting of intact purkinje axons in the cerebellum of the adult rat. J Neurosci 25:7150-7158. CrossRef Medline

D’Angelo E, De Zeeuw CI (2009) Timing and plasticity in the cerebellum: focus on the granular layer. Trends Neurosci 32:30-40. CrossRef Medline

D’Angelo E, Solinas S, Mapelli J, Gandolfi D, Mapelli L, Prestori F (2013) The cerebellar Golgi cell and spatiotemporal organization of granular layer activity. Front Neural Circuits 7:93. CrossRef Medline

Deepa SS, Umehara Y, Higashiyama S, Itoh N, Sugahara K (2002) Specific molecular interactions of oversulfated chondroitin sulfate $\mathrm{E}$ with various heparin-binding growth factors. Implications as a physiological binding partner in the brain and other tissues. J Biol Chem 277:43707-43716. CrossRef Medline

Deepa SS, Carulli D, Galtrey C, Rhodes K, Fukuda J, Mikami T, Sugahara K, Fawcett JW (2006) Composition of perineuronal net extracellular matrix in rat brain: a different disaccharide composition for the net-associated proteoglycans. J Biol Chem 281:17789-17800. CrossRef Medline

de Winter F, Kwok JC, Fawcett JW, Vo TT, Carulli D, Verhaagen J (2016) The chemorepulsive protein semaphorin $3 \mathrm{~A}$ and perineuronal netmediated plasticity. Neural Plast 2016:3679545. CrossRef Medline

Dick G, Tan CL, Alves JN, Ehlert EM, Miller GM, Hsieh-Wilson LC, Sugahara K, Oosterhof A, van Kuppevelt TH, Verhaagen J, Fawcett JW, Kwok JC (2013) Semaphorin 3A binds to the perineuronal nets via chondroitin sulfate type E motifs in rodent brains. J Biol Chem 288:27384-27395. CrossRef Medline

Dietrich JB, Mangeol A, Revel MO, Burgun C, Aunis D, Zwiller J (2005) Acute or repeated cocaine administration generates reactive oxygen species and induces antioxidant enzyme activity in dopaminergic rat brain structures. Neuropharmacology 48:965-974. CrossRef Medline

Dityatev A, Rusakov DA (2011) Molecular signals of plasticity at the tetrapartite synapse. Curr Opin Neurobiol 21:353-359. CrossRef Medline

Dityatev A, Schachner M (2003) Extracellular matrix molecules and synaptic plasticity. Nat Rev Neurosci 4:456-468. CrossRef Medline

Dityatev A, Brückner G, Dityateva G, Grosche J, Kleene R, Schachner M 
(2007) Activity-dependent formation and functions of chondroitin sulfate-rich extracellular matrix of perineuronal nets. Dev Neurobiol 67: 570-588. CrossRef Medline

Donato F, Rompani SB, Caroni P (2013) Parvalbumin-expressing basketcell network plasticity induced by experience regulates adult learning. Nature 504:272-276. CrossRef Medline

Dours-Zimmermann MT, Maurer K, Rauch U, Stoffel W, Fässler R, Zimmermann DR (2009) Versican V2 assembles the extracellular matrix surrounding the nodes of ranvier in the CNS. J Neurosci 29:7731-7742. CrossRef Medline

Duman RS (2014) Pathophysiology of depression and innovative treatments: remodeling glutamatergic synaptic connections. Dialogues Clin Neurosci 16:11-27. Medline

Dziembowska M, Pretto DI, Janusz A, Kaczmarek L, Leigh MJ, Gabriel N, Durbin-Johnson B, Hagerman RJ, Tassone F (2013) High MMP-9 activity levels in fragile $\mathrm{X}$ syndrome are lowered by minocycline. Am J Med Genet A 161A:1897-1903. CrossRef Medline

Eastwood SL, Law AJ, Everall IP, Harrison PJ (2003) The axonal chemorepellant semaphorin $3 \mathrm{~A}$ is increased in the cerebellum in schizophrenia and may contribute to its synaptic pathology. Mol Psychiatry 8:148-155. CrossRef Medline

Everitt BJ, Robbins TW (2005) Neural systems of reinforcement for drug addiction: from actions to habits to compulsion. Nat Neurosci 8:14811489. CrossRef Medline

Faissner A, Pyka M, Geissler M, Sobik T, Frischknecht R, Gundelfinger ED, Seidenbecher C (2010) Contributions of astrocytes to synapse formation and maturation: potential functions of the perisynaptic extracellular matrix. Brain Res Rev 63:26-38. CrossRef Medline

Fatemi SH (2005) Reelin glycoprotein: structure, biology and roles in health and disease. Mol Psychiatry 10:251-257. CrossRef Medline

Fatemi SH (2010) Co-occurrence of neurodevelopmental genes in etiopathogenesis of autism and schizophrenia. Schizophr Res 118:303-304. CrossRef Medline

Fatemi SH, Snow AV, Stary JM, Araghi-Niknam M, Reutiman TJ, Lee S, Brooks AI, Pearce DA (2005) Reelin signaling is impaired in autism. Biol Psychiatry 57:777-787. CrossRef Medline

Fawcett J (2009) Molecular control of brain plasticity and repair. Prog Brain Res 175:501-509. CrossRef Medline

Fawcett JW (2015) The extracellular matrix in plasticity and regeneration after CNS injury and neurodegenerative disease. Prog Brain Res 218:213226. CrossRef Medline

Folsom TD, Fatemi SH (2013) The involvement of Reelin in neurodevelopmental disorders. Neuropharmacology 68:122-135. CrossRef Medline

Frischknecht R, Gundelfinger ED (2012) The brain's extracellular matrix and its role in synaptic plasticity. Adv Exp Med Biol 970:153-171. CrossRef Medline

Frischknecht R, Heine M, Perrais D, Seidenbecher CI, Choquet D, Gundelfinger ED (2009) Brain extracellular matrix affects AMPA receptor lateral mobility and short-term synaptic plasticity. Nat Neurosci 12:897904. CrossRef Medline

Galtrey CM, Fawcett JW (2007) The role of chondroitin sulfate proteoglycans in regeneration and plasticity in the central nervous system. Brain Res Rev 54:1-18. CrossRef Medline

Galtrey CM, Kwok JC, Carulli D, Rhodes KE, Fawcett JW (2008) Distribution and synthesis of extracellular matrix proteoglycans, hyaluronan, link proteins and tenascin-R in the rat spinal cord. Eur J Neurosci 27:13731390. CrossRef Medline

Giamanco KA, Morawski M, Matthews RT (2010) Perineuronal net formation and structure in aggrecan knockout mice. Neuroscience 170:13141327. CrossRef Medline

Gogolla N, Caroni P, Lüthi A, Herry C (2009) Perineuronal nets protect fear memories from erasure. Science 325:1258-1261. CrossRef Medline

Gu Y, Huang S, Chang MC, Worley P, Kirkwood A, Quinlan EM (2013) Obligatory role for the immediate early gene NARP in critical period plasticity. Neuron 79:335-346. CrossRef Medline

Guidotti A, Pesold C, Costa E (2000a) New neurochemical markers for psychosis: a working hypothesis of their operation [In Process Citation]. Neurochem Res 25:1207-1218. CrossRef Medline

Guidotti A, Auta J, Davis JM, Di-Giorgi-Gerevini V, Dwivedi Y, Grayson DR, Impagnatiello F, Pandey G, Pesold C, Sharma R, Uzunov D, Costa E, DiGiorgi Gerevini V (2000b) Decrease in reelin and glutamic acid decarboxylase67 (GAD67) expression in schizophrenia and bipolar disor- der: a postmortem brain study. Arch Gen Psychiatry 57:1061-1069. CrossRef Medline

Happel MF, Niekisch H, Castiblanco Rivera LL, Ohl FW, Deliano M, Frischknecht R (2014) Enhanced cognitive flexibility in reversal learning induced by removal of the extracellular matrix in auditory cortex. Proc Natl Acad Sci U S A 111:2800-2805. CrossRef Medline

Härtig W, Brauer K, Brückner G (1992) Wisteria floribunda agglutininlabelled nets surround parvalbumin-containing neurons. Neuroreport 3:869-872. CrossRef Medline

Härtig W, Derouiche A, Welt K, Brauer K, Grosche J, Mäder M, Reichenbach A, Brückner G (1999) Cortical neurons immunoreactive for the potassium channel Kv3.1b subunit are predominantly surrounded by perineuronal nets presumed as a buffering system for cations. Brain Res 842: 15-29. CrossRef Medline

Hobohm C, Härtig W, Brauer K, Brückner G (1998) Low expression of extracellular matrix components in rat brain stem regions containing modulatory aminergic neurons. J Chem Neuroanat 15:135-142. CrossRef Medline

Horii-Hayashi N, Sasagawa T, Hashimoto T, Kaneko T, Takeuchi K, Nishi M (2015) A newly identified mouse hypothalamic area having bidirectional neural connections with the lateral septum: the perifornical area of the anterior hypothalamus enriched in chondroitin sulfate proteoglycans. Eur J Neurosci 42:2322-2334. CrossRef Medline

Hussman JP, Chung RH, Griswold AJ, Jaworski JM, Salyakina D, Ma D, Konidari I, Whitehead PL, Vance JM, Martin ER, Cuccaro ML, Gilbert JR, Haines JL, Pericak-Vance MA (2011) A noise-reduction GWAS analysis implicates altered regulation of neurite outgrowth and guidance in autism. Mol Autism 2:1. CrossRef Medline

Hustvedt S (2014) The blazing world. In: His words stayed with me as only a few sentences do over the course of a lifetime. A writer, whose name I can't remember now, called these verbal memories "brain tattoos." New York: Simon and Schuster.

Hylin MJ, Orsi SA, Moore AN, Dash PK (2013) Disruption of the perineuronal net in the hippocampus or medial prefrontal cortex impairs fear conditioning. Learn Mem 20:267-273. CrossRef Medline

Hyman SE, Malenka RC, Nestler EJ (2006) Neural mechanisms of addiction: the role of reward-related learning and memory. Annu Rev Neurosci 29:565-598. CrossRef Medline

Jang EY, Ryu YH, Lee BH, Chang SC, Yeo MJ, Kim SH, Folsom RJ, Schilaty ND, Kim KJ, Yang CH, Steffensen SC, Kim HY (2015) Involvement of reactive oxygen species in cocaine-taking behaviors in rats. Addict Biol 20:663-675. CrossRef Medline

Kalb RG, Hockfield S (1990) Induction of a neuronal proteoglycan by the NMDA receptor in the developing spinal cord. Science 250:294-296. CrossRef Medline

Kalivas PW, Volkow ND (2005) The neural basis of addiction: a pathology of motivation and choice. Am J Psychiatry 162:1403-1413. CrossRef Medline

Kasanetz F, Deroche-Gamonet V, Berson N, Balado E, Lafourcade M, Manzoni O, Piazza PV (2010) Transition to addiction is associated with a persistent impairment in synaptic plasticity. Science 328:1709-1712. CrossRef Medline

Kitagawa H, Tsutsumi K, Tone Y, Sugahara K (1997) Developmental regulation of the sulfation profile of chondroitin sulfate chains in the chicken embryo brain. J Biol Chem 272:31377-31381. CrossRef Medline

Köppe G, Brückner G, Härtig W, Delpech B, Bigl V (1997) Characterization of proteoglycan-containing perineuronal nets by enzymatic treatments of rat brain sections. Histochem J 29:11-20. CrossRef Medline

Kwok JC, Carulli D, Fawcett JW (2010) In vitro modeling of perineuronal nets: hyaluronan synthase and link protein are necessary for their formation and integrity. J Neurochem 114:1447-1459. CrossRef Medline

Kwok JC, Dick G, Wang D, Fawcett JW (2011) Extracellular matrix and perineuronal nets in CNS repair. Dev Neurobiol 71:1073-1089. CrossRef Medline

Lee H, Leamey CA, Sawatari A (2012) Perineuronal nets play a role in regulating striatal function in the mouse. PLoS One 7:e32747. CrossRef Medline

Lewis DA, Hashimoto T, Volk DW (2005) Cortical inhibitory neurons and schizophrenia. Nat Rev Neurosci 6:312-324. CrossRef Medline

Lin R, Rosahl TW, Whiting PJ, Fawcett JW, Kwok JC (2011) 6-Sulphated chondroitins have a positive influence on axonal regeneration. PLoS One 6:e21499. CrossRef Medline

Lubbers BR, Smit AB, Spijker S, van den Oever MC (2014) Neural ECM in 
addiction, schizophrenia, and mood disorder. Prog Brain Res 214:263284. CrossRef Medline

Maeda N, Fukazawa N, Ishii M (2010) Chondroitin sulfate proteoglycans in neural development and plasticity. Front Biosci (Landmark Ed) 15:626644. CrossRef Medline

Mahler SV, Vazey EM, Beckley JT, Keistler CR, McGlinchey EM, Kaufling J, Wilson SP, Deisseroth K, Woodward JJ, Aston-Jones G (2014) Designer receptors show role for ventral pallidum input to ventral tegmental area in cocaine seeking. Nat Neurosci 17:577-585. CrossRef Medline

Mapelli J, D’Angelo E (2007) The spatial organization of long-term synaptic plasticity at the input stage of cerebellum. J Neurosci 27:1285-1296. CrossRef Medline

Mash DC, ffrench-Mullen J, Adi N, Qin Y, Buck A, Pablo J (2007) Gene expression in human hippocampus from cocaine abusers identifies genes which regulate extracellular matrix remodeling. PLoS One 2:e1187. CrossRef Medline

Massey JM, Hubscher CH, Wagoner MR, Decker JA, Amps J, Silver J, Onifer SM (2006) Chondroitinase ABC digestion of the perineuronal net promotes functional collateral sprouting in the cuneate nucleus after cervical spinal cord injury. J Neurosci 26:4406-4414. CrossRef Medline

Matthews RT, Kelly GM, Zerillo CA, Gray G, Tiemeyer M, Hockfield S (2002) Aggrecan glycoforms contribute to the molecular heterogeneity of perineuronal nets. J Neurosci 22:7536-7547. Medline

Mauney SA, Athanas KM, Pantazopoulos H, Shaskan N, Passeri E, Berretta S, Woo TU (2013) Developmental pattern of perineuronal nets in the human prefrontal cortex and their deficit in schizophrenia. Biol Psychiatry 74:427-435. CrossRef Medline

McRae PA, Porter BE (2012) The perineuronal net component of the extracellular matrix in plasticity and epilepsy. Neurochem Int 61:963-972. CrossRef Medline

Mészár Z, Girard F, Saper CB, Celio MR (2012) The lateral hypothalamic parvalbumin-immunoreactive (PV1) nucleus in rodents. J Comp Neurol 520:798-815. CrossRef Medline

Mikami T, Kitagawa H (2013) Biosynthesis and function of chondroitin sulfate. Biochim Biophys Acta 1830:4719-4733. CrossRef Medline

Minzenberg MJ, Firl AJ, Yoon JH, Gomes GC, Reinking C, Carter CS (2010) Gamma oscillatory power is impaired during cognitive control independent of medication status in first-episode schizophrenia. Neuropsychopharmacology 35:2590-2599. CrossRef Medline

Miquel M, Vazquez-Sanroman D, Carbo-Gas M, Gil-Miravet I, SanchisSegura C, Carulli D, Manzo J, Coria-Avila GA (2016) Have we been ignoring the elephant in the room? Seven arguments for considering the cerebellum as part of addiction circuitry. Neurosci Biobehav Rev 60:1-11. CrossRef Medline

Miyata S, Kitagawa H (2015) Mechanisms for modulation of neural plasticity and axon regeneration by chondroitin sulphate. J Biochem 157:13-22. CrossRef Medline

Miyata S, Kitagawa H (2016) Chondroitin 6-sulfation regulates perineuronal net formation by controlling the stability of aggrecan. Neural Plast 2016:1305801. CrossRef Medline

Miyata S, Komatsu Y, Yoshimura Y, Taya C, Kitagawa H (2012) Persistent cortical plasticity by upregulation of chondroitin 6-sulfation. Nat Neurosci 15:414-422. CrossRef Medline

Morawski M, Brückner MK, Riederer P, Brückner G, Arendt T (2004) Perineuronal nets potentially protect against oxidative stress. Exp Neurol 188:309-315. CrossRef Medline

Moussawi K, Pacchioni A, Moran M, Olive MF, Gass JT, Lavin A, Kalivas PW (2009) N-Acetylcysteine reverses cocaine-induced metaplasticity. Nat Neurosci 12:182-189. CrossRef Medline

Nicholson C, Syková E (1998) Extracellular space structure revealed by diffusion analysis. Trends Neurosci 21:207-215. CrossRef Medline

Numa R, Kohen R, Poltyrev T, Yaka R (2008) Tempol diminishes cocaineinduced oxidative damage and attenuates the development and expression of behavioral sensitization. Neuroscience 155:649-658. CrossRef Medline

Okuda H, Tatsumi K, Horii-Hayashi N, Morita S, Okuda-Yamamoto A, Imaizumi K, Wanaka A (2014) OASIS regulates chondroitin 6-Osulfotransferase 1 gene transcription in the injured adult mouse cerebral cortex. J Neurochem 130:612-625. CrossRef Medline

Orekhova EV, Stroganova TA, Nygren G, Tsetlin MM, Posikera IN, Gillberg C, Elam M (2007) Excess of high frequency electroencephalogram oscil- lations in boys with autism. Biol Psychiatry 62:1022-1029. CrossRef Medline

Pantazopoulos H, Murray EA, Berretta S (2008) Total number, distribution, and phenotype of cells expressing chondroitin sulfate proteoglycans in the normal human amygdala. Brain Res 1207:84-95. CrossRef Medline

Pantazopoulos H, Woo TU, Lim MP, Lange N, Berretta S (2010) Extracellular matrix-glial abnormalities in the amygdala and entorhinal cortex of subjects diagnosed with schizophrenia. Arch Gen Psychiatry 67:155-166. CrossRef Medline

Pantazopoulos H, Markota M, Jaquet F, Ghosh D, Wallin A, Santos A, Caterson B, Berretta S (2015) Aggrecan and chondroitin-6-sulfate abnormalities in schizophrenia and bipolar disorder: a postmortem study on the amygdala. Transl Psychiatry 5:e496. CrossRef Medline

Pelkey KA, Barksdale E, Craig MT, Yuan X, Sukumaran M, Vargish GA, Mitchell RM, Wyeth MS, Petralia RS, Chittajallu R, Karlsson RM, Cameron HA, Murata Y, Colonnese MT, Worley PF, McBain CJ (2015) Pentraxins coordinate excitatory synapse maturation and circuit integration of parvalbumin interneurons. Neuron 85:1257-1272. CrossRef Medline

Penzes P, Buonanno A, Passafaro M, Sala C, Sweet RA (2013) Developmental vulnerability of synapses and circuits associated with neuropsychiatric disorders. J Neurochem 126:165-182. CrossRef Medline

Pizzorusso T, Medini P, Berardi N, Chierzi S, Fawcett JW, Maffei L (2002) Reactivation of ocular dominance plasticity in the adult visual cortex. Science 298:1248-1251. CrossRef Medline

Prasad KM, Patel AR, Muddasani S, Sweeney J, Keshavan MS (2004) The entorhinal cortex in first-episode psychotic disorders: a structural magnetic resonance imaging study. Am J Psychiatry 161:1612-1619. CrossRef Medline

Rhodes KE, Fawcett JW (2004) Chondroitin sulphate proteoglycans: preventing plasticity or protecting the CNS? J Anat 204:33-48. CrossRef Medline

Roggeri L, Rivieccio B, Rossi P, D’Angelo E (2008) Tactile stimulation evokes long-term synaptic plasticity in the granular layer of cerebellum. J Neurosci 28:6354-6359. CrossRef Medline

Romberg C, Yang S, Melani R, Andrews MR, Horner AE, Spillantini MG, Bussey TJ, Fawcett JW, Pizzorusso T, Saksida LM (2013) Depletion of perineuronal nets enhances recognition memory and long-term depression in the perirhinal cortex. J Neurosci 33:7057-7065. CrossRef Medline

Schizophrenia Working Group of the Psychiatric Genomics Consortium (2014) Biological insights from 108 schizophrenia-associated genetic loci. Nature 511:421-427. CrossRef Medline

Schüppel K, Brauer K, Härtig W, Grosche J, Earley B, Leonard BE, Brückner G (2002) Perineuronal nets of extracellular matrix around hippocampal interneurons resist destruction by activated microglia in trimethyltintreated rats. Brain Res 958:448-453. CrossRef Medline

Seeger G, Brauer K, Härtig W, Brückner G (1994) Mapping of perineuronal nets in the rat brain stained by colloidal iron hydroxide histochemistry and lectin cytochemistry. Neuroscience 58:371-388. CrossRef Medline

Slaker M, Churchill L, Todd RP, Blacktop JM, Zuloaga DG, Raber J, Darling RA, Brown TE, Sorg BA (2015) Removal of perineuronal nets in the medial prefrontal cortex impairs the acquisition and reconsolidation of a cocaine-induced conditioned place preference memory. J Neurosci 35: 4190-4202. CrossRef Medline

Slaker M, Blacktop JM, Sorg BA (2016) Caught in the net: perineuronal nets and addiction. Neural Plast 2016:7538208. CrossRef Medline

Smith AC, Kupchik YM, Scofield MD, Gipson CD, Wiggins A, Thomas CA, Kalivas PW (2014) Synaptic plasticity mediating cocaine relapse requires matrix metalloproteinases. Nat Neurosci 17:1655-1657. CrossRef Medline

Smith AC, Scofield MD, Kalivas PW (2015) The tetrapartite synapse: extracellular matrix remodeling contributes to corticoaccumbens plasticity underlying drug addiction. Brain Res 1628:29-39. CrossRef Medline

Smith KS, Tindell AJ, Aldridge JW, Berridge KC (2009) Ventral pallidum roles in reward and motivation. Behav Brain Res 196:155-167. CrossRef Medline

Soleman S, Filippov MA, Dityatev A, Fawcett JW (2013) Targeting the neural extracellular matrix in neurological disorders. Neuroscience 253:194213. CrossRef Medline

Sordi AO, Pechansky F, Kessler FH, Kapczinski F, Pfaffenseller B, Gubert C, de Aguiar BW, de Magalhães Narvaez JC, Ornell F, von Diemen L (2014) Oxidative stress and BDNF as possible markers for the severity of crack 
cocaine use in early withdrawal. Psychopharmacology 231:4031-4039. CrossRef Medline

Spatazza J, Di Lullo E, Joliot A, Dupont E, Moya KL, Prochiantz A (2013) Homeoprotein signaling in development, health, and disease: a shaking of dogmas offers challenges and promises from bench to bed. Pharmacol Rev 65:90-104. CrossRef Medline

Spreafico R, De Biasi S, Vitellaro-Zuccarello L (1999) The perineuronal net: a weapon for a challenge. J Hist Neurosci 8:179-185. CrossRef Medline

Steullet P, Cabungcal JH, Cuénod M, Do KQ (2014) Fast oscillatory activity in the anterior cingulate cortex: dopaminergic modulation and effect of perineuronal net loss. Front Cell Neurosci 8:244. CrossRef Medline

Suttkus A, Morawski M, Arendt T (2016) Protective properties of neural extracellular matrix. Mol Neurobiol 53:73-82. CrossRef Medline

Syková E (2004) Diffusion properties of the brain in health and disease. Neurochem Int 45:453-466. CrossRef Medline

Tissir F, Goffinet AM (2003) Reelin and brain development. Nat Rev Neurosci 4:496-505. CrossRef Medline

Van den Oever MC, Lubbers BR, Goriounova NA, Li KW, Van der Schors RC, Loos M, Riga D, Wiskerke J, Binnekade R, Stegeman M, Schoffelmeer AN, Mansvelder HD, Smit AB, De Vries TJ, Spijker S (2010) Extracellular matrix plasticity and GABAergic inhibition of prefrontal cortex pyramidal cells facilitates relapse to heroin seeking. Neuropsychopharmacology 35:2120-2133. CrossRef Medline

Vazquez-Sanroman D, Leto K, Cerezo-Garcia M, Carbo-Gas M, SanchisSegura C, Carulli D, Rossi F, Miquel M (2015a) The cerebellum on cocaine: plasticity and metaplasticity. Addict Biol 20:941-955. CrossRef Medline

Vazquez-Sanroman D, Carbo-Gas M, Leto K, Cerezo-Garcia M, Gil-Miravet I, Sanchis-Segura C, Carulli D, Rossi F, Miquel M (2015b) Cocaineinduced plasticity in the cerebellum of sensitised mice. Psychopharmacology 232:4455-4467. CrossRef Medline

Vitellaro-Zuccarello L, Bosisio P, Mazzetti S, Monti C, De Biasi S (2007) Differential expression of several molecules of the extracellular matrix in functionally and developmentally distinct regions of rat spinal cord. Cell Tissue Res 327:433-447. CrossRef Medline

Vo T, Carulli D, Ehlert EM, Kwok JC, Dick G, Mecollari V, Moloney EB, Neufeld G, de Winter F, Fawcett JW, Verhaagen J (2013) The chemore- pulsive axon guidance protein semaphorin $3 \mathrm{~A}$ is a constituent of perineuronal nets in the adult rodent brain. Mol Cell Neurosci 56:186-200. CrossRef Medline

Wang D, Fawcett J (2012) The perineuronal net and the control of CNS plasticity. Cell Tissue Res 349:147-160. CrossRef Medline

Wang H, Katagiri Y, McCann TE, Unsworth E, Goldsmith P, Yu ZX, Tan F, Santiago L, Mills EM, Wang Y, Symes AJ, Geller HM (2008) Chondroitin4-sulfation negatively regulates axonal guidance and growth. J Cell Sci 121: 3083-3091. CrossRef Medline

Wegner F, Härtig W, Bringmann A, Grosche J, Wohlfarth K, Zuschratter W, Brückner G (2003) Diffuse perineuronal nets and modified pyramidal cells immunoreactive for glutamate and the GABA(A) receptor alphal subunit form a unique entity in rat cerebral cortex. Exp Neurol 184:705714. CrossRef Medline

Weiss LA, Arking DE, Gene Discovery Project of Johns Hopkins \& the Autism Consortium, Daly MJ, Chakravarti A (2009) A genome-wide linkage and association scan reveals novel loci for autism. Nature 461:802-808. CrossRef Medline

Xu X, Miller EC, Pozzo-Miller L (2014) Dendritic spine dysgenesis in Rett syndrome. Front Neuroanat 8:97. CrossRef Medline

Xue YX, Xue LF, Liu JF, He J, Deng JH, Sun SC, Han HB, Luo YX, Xu LZ, Wu P, Lu L (2014) Depletion of perineuronal nets in the amygdala to enhance the erasure of drug memories. J Neurosci 34:6647-6658. CrossRef Medline

Yamada J, Ohgomori T, Jinno S (2015) Perineuronal nets affect parvalbumin expression in GABAergic neurons of the mouse hippocampus. Eur J Neurosci 41:368-378. CrossRef Medline

Yang S, Cacquevel M, Saksida LM, Bussey TJ, Schneider BL, Aebischer P, Melani R, Pizzorusso T, Fawcett JW, Spillantini MG (2015) Perineuronal net digestion with chondroitinase restores memory in mice with tau pathology. Exp Neurol 265:48-58. CrossRef Medline

Yi JH, Katagiri Y, Susarla B, Figge D, Symes AJ, Geller HM (2012) Alterations in sulfated chondroitin glycosaminoglycans following controlled cortical impact injury in mice. J Comp Neurol 520:3295-3313. CrossRef Medline

Yutsudo N, Kitagawa H (2015) Involvement of chondroitin 6-sulfation in temporal lobe epilepsy. Exp Neurol 274:126-133. CrossRef Medline 